\title{
Committed to trouble. Learning from teachers' stories of challenging yet rewarding
}

\section{teacher-student relationships.}

\author{
Anna Rytivaara, University of Tampere, Finland
}

Anneli Frelin, University of Gävle, Sweden

\begin{abstract}
Teacher-student relationships are vital for student learning, yet they can be experienced as a burden by teachers and cause teacher attrition. This paper is based on the stories of six teachers who gave accounts of relationships with students that, counterintuitively, were both problematic and positive. Narrative analysis was applied to these accounts in order to disentangle the complexities of teaching and better understand what factors led the teachers to find the challenge of difficult teacher-student relationships ultimately rewarding.
\end{abstract}

Keywords Teacher-student relationships; teacher narratives; teacher knowledge; teacher commitment

\section{Introduction}

The literature contains many "hero stories" about teachers who made difference in the lives of individual students. But beyond the glossy success stories, less attention has been paid to the teacher's perspective and the difficult struggles that have laid the foundation for these triumphs. In the contemporary educational debate, the role of teacher-student relationships in students' learning has been approached from various directions in different countries (e.g. Eldor \& Shoshani, 2016; Johnson, 2008; Lee, 2007; Pianta, 2006; Wubbels, Brekelmans, den Brok, \& van Tartwijk, 2006). However, training and retaining good teachers is a challenge faced by many countries (OECD, 2011). The age of the global knowledge economy and international assessments such as PISA has not improved the situation; rather, it has given rise 
to concerns in several countries as to the competitiveness of their educational systems, and in the search for answers teachers have been pinpointed as both saviours and as part of the problem.

Teacher-student relationships are an essential aspect of teachers' everyday work in the classroom. While the daily interaction of teachers with students can constitute an important source of sustained professional commitment (Day \& Gu, 2010; Fransson \& Frelin, 2016), it is also considered one of the most difficult skills in teaching (Wideen, Mayer-Smith, \& Moon, 1998), and may as a result cause emotional exhaustion, leading to teacher attrition (Skaalvik \& Skaalvik, 2011). In the classroom environment, teachers and students are involved in subtle and complex negotiations that shape their academic work (Doyle, 2006; Frelin, 2013). These may become dramatically visible in situations of a conflict or break in relationships, but to the outside observer they often reside below the surface of regular classroom life. In the oftencited study Visible learning by Hattie, stress was laid on the importance of perspective-taking on the part of the teacher, meaning that the teacher should be able to understand the student's views and motivations (Hattie, 2009). However, this meta-meta-analysis (Hattie, 2009) did not include qualitative research, which answers other types of research questions on how teachers can manage their work and help students learn (cf. Uitto, Jokikokko, \& Estola, 2015).

In order to contribute to the field of teacher commitment, this article explores teachers' personal stories with a focus on complex and seemingly counterintuitive examples of challenging teacher-student relationships that teachers actually found rewarding. The main perspective is on teacher-student relationships as an integral part of a teacher's professional knowledge landscape (Clandinin \& Connelly, 1996) that we will explore through six Swedish teachers' stories on their students. The stories promote our understanding of the varied dimensions of teachers' landscapes, which include both the personal and professional, individual and collective, and local and global. Moreover, stories about difficult teacher- 
student interaction can enhance understanding of how to build and sustain educational relationships with students. Research on teacher resilience indicates that the capacity for resilience is relationally conceived and enables teachers to sustain their commitment in the face of challenging circumstances in their everyday teaching (Day \& Gu, 2014; Gu, 2014), and that supportive school cultures are of vital importance for teacher commitment and effectiveness (Craig, 2013; Day \& Gu, 2014; Sammons et al., 2007).

The aim of this article is to contribute to the qualitative research on teachers' work by exploring how contradictions and tensions evolve in teachers' stories about students with whom they have experienced challenging yet rewarding relationships.

\section{Theoretical framework}

\subsection{Teacher knowledge and emotions}

The practical knowledge needed to deal with the everyday challenges of classroom life has increasingly been a focus of research. An early major influence in this field was Shulman (1987, 2004), who distinguished between content knowledge, general pedagogical knowledge, curriculum knowledge, pedagogical content knowledge, knowledge of learners, knowledge of educational contexts and knowledge of educational ends, purposes and values. Others, like Elbaz (1983) and Grossman (1995), contributed the notion of knowledge of self to teachers' practical knowledge. In general, the concept nowadays carries a wider meaning than earlier (Ben-Peretz, 2011).

Recognition of the value of practical knowledge has directed attention to the connection between professionality and emotions (Entwistle, Skinner, Entwistle, \& Orr, 2000; Hargreaves, 1998, 2000; Nias, 1996), although, according to Uitto, Jokikokko, \& Estola (2015), this connection is in need of further research. When teachers make decisions regarding their students, these include feelings as well as knowledge, and hence a teacher's 
commitment is based on caring as well as on erudition (Ball \& Wilson, 1996). The separation of emotions and cognition has been variously criticised, largely based on the argument that emotions have cognitive roots (Nias, 1996; Nussbaum, 1997). Moreover, emotions in teaching have often been seen as distinct from professionality (Hargreaves, 2000). Teachers invest emotionally in their students, yet this feature of the teacher's role has been largely overlooked in the discussion of policy and standards (O'Connor, 2008; Zembylas, 2007). Hargreaves (2000) argued that teaching is an irretrievably emotional activity, and that teachers' understanding of their students partially results from learning to "read" them on the basis of observations. The emotional bonds that teachers create together with students can serve to sustain teacher commitment (Collie, Shapka, \& Perry, 2011; Gu, 2014; Gu \& Day, 2013), but can also challenge teachers' self-image and evoke feelings of vulnerability (Kelchtermans, 2009). It has been suggested that teachers can be helped to manage their work by adopting four understandings: "acknowledging that teaching is an emotional profession, identifying and reflecting on emotions and the underlying cognitive appraisals, regulating their emotions appropriately, and coping with emotions effectively" (Chang, 2009, p. 212).

\subsection{Knowledge landscapes}

Our theoretical and methodological starting point is that teachers' work, experiences and knowledge form an intertwined system (Kelchtermans, 1993), and thus we need to understand individual teachers with their unique experiences to understand their actions in the classrooms (Day \& Gu, 2010). In particular, this paper is based on a narrative approach where teacher knowledge is understood as "the sum total of the teacher's experiences" (Connelly, Clandinin, \& He, 1997, p. 666). Two decades ago, Clandinin, Connelly and Fang (1997) introduced the metaphors of practical and professional knowledge landscapes to refer to the complex environment in which teachers work (Clandinin \& Connelly, 1995; Connelly et al., 1997). The idea of a landscape illustrates how teachers' work is highly relational and 
embedded in moments, moments filled with past experiences, with present emotions and with future expectations and hopes. Because of the dynamics on the micro and macro levels, the school environment is constantly in flux, which means that the ability to manage these changes becomes part of teachers' knowledge (Clandinin, Downey, \& Huber, 2009).

Moreover, in the narrative framework adopted in this paper, experiences are narrative constructions (Clandinin \& Connelly, 2000, p. 124-125); stories are narrated experiences. This relation between teacher narratives, experiences and knowledge makes stories an effective means to understand teacher-student relationships from the perspective of professional knowledge as "narratively composed, embodied in a person, and expressed in practice." (Clandinin \& Connelly, 2000, p. 124).

\subsection{Teacher-student relationships}

The importance of positive teacher-student relationships as part of a productive educational environment both for student learning (Cornelius-White, 2007; Doyle, 2006; Evertson \& Weinstein, 2006; Hamre \& Pianta, 2001; Pianta, 2006; Roorda, Koomen, Spilt, \& Oort, 2011; Wentzel, Battle, Russell, \& Looney, 2010; Wu, Hughes \& Kwok, 2010) and for teacher well-being (Sammons et al., 2007; Veldman, van Tartwijk, Brekelmans, \& Wubbels, 2013; Wubbels et al., 2006) is well established. Teachers' work can promote positive student outcomes (Cornelius-White, 2007), and behaviour (Brackett, Reyes, Rivers, Elbertson, \& Salovey, 2011). student engagement (Margonis, 2004), and self-esteem (Pianta, 2006). When it comes to creating positive social relationships among students, teachers are central (Sprott, 2004). Closeness in teacher-student relationships has positive effect on student confidence and effort (see e.g. den Brok, Levy, Brekelmans, \& Wubbels, 2005), subject-specific motivation (Davis, 2003; den Brok et al., 2005; Lingard, Hayes, \& Mills, 2003) and resilience (Johnson, 2008). For teachers, the emotional rewards of teacher-student relationships help them stay committed (Day \& Gu, 2007; Fransson \& Frelin, 2016). 
However, getting “over-involved” may constitute a problem for teachers' working capacity (Aultman et al., 2009). It should be noted that occurences of negative events are less detrimental to teacher commitment than the absence of positive experiences (Morgan, Ludlow, Kitching, O'Leary, \& Clarke, 2010).

Moreover, a positive teacher-student relationship is important above all for students who come to school already disadvantaged compared to their peers (Davidson, 1999; Hamre \& Pianta, 2001; Honkasilta, Vehkakoski, \& Vehmas, 2016; Johnson, 2008). In positive teacher-student relationships, teachers' behaviour can be summarised as warm demanders (Woolfolk Hoy \& Weinstein, 2006), that is, it combines expressions of care within a structured environment. Teachers in positive relationships found students agreeable and motivated, and even if problematic, student behaviour did not necessarily cause a break in the relationship it contributed to teacher stress (Claessens et al., 2016).

Whereas everyday interactions form the basis of teacher-student relationships, understanding of how these actually contribute to the relationship has been less researched (Pennings et al., 2014), partly because these qualities have been difficult to study (Rodgers \& Raider-Roth, 2006). Mackenzie (2013) studied the rewards perceived by teachers working with students with special educational needs and found that "making a difference" was the common denominator, whether on the micro level of the teacher-student relationship or on the macro level of changing the system.

\section{Methods}

\subsection{The Swedish context}

Sweden has long been a highly developed welfare state and Swedish schools have a long tradition of a free, publicly funded comprehensive and equal educational system which, at the time of the data collection, was municipally organised (with very few exceptions). 
Compulsory schooling in Sweden typically follows three stages, grades 1-3 (ages 7-9), 4-6 (ages 10-12) and 7-9 (ages 13-15). Almost all students continue into upper secondary school (typically ages 16-18). At the time of the data collection a new version of the National Curriculum had just been implemented, along with reforms involving de-regulation and decentralization, and hence the teaching profession was trying to adjust to a goal-oriented steering system and emerging marketization. During the 1990s, the rhetoric of teachers as professionals was prominent.

It should be noted that Swedish teachers of younger students often loop, meaning that they typically form relationships with students that last several years, during which they meet the same students each day and for most of the time that they spend in school. These conditions are good for establishing close relationships with both teachers and classmates, and are not seen as impediments to learning. In contrast to other countries such as the United States, there are no issues of the no-touch kind, meaning that a pat on the shoulder or sitting in the teacher's lap is not viewed as inappropriate for younger students.

\subsection{Data}

The data for this paper are drawn from an extensive research project on teachers' lives and work over time. In this project, 87 graduates from a teacher education college program in Sweden were followed from 1993 and data collection on this cohort is still ongoing (see e.g. Fransson \& Frelin, 2016; Lindqvist, Nordänger, \& Carlsson, 2014; Lindqvist \& Nordänger, 2016). Written questionnaires were administered on ten different occasions during the study years (85-100\% response rate); in this paper we focus on two open-ended questions asked in the third questionnaire in 1995:

- Describe one student who has caused you a lot of trouble over the past school year.

What have you done to come to terms with the problem?

- Describe one student who has given you much joy over the past school year. 
We were particularly interested in the answers of the ten teachers who identified the same student in their answers to both questions, as at first this seemed counterintuitive. We locate the data in a narrative framework where the teachers' answers to the two open-ended questionnaire questions are considered as stories that reveal the teachers' experiences as teachers and make it possible to explore these, while noting that stories are always told in a specific moment and context (Clandinin \& Rosiek, 2007; Cortazzi \& Lin, 2006; Lieblich, Tuval-Mashiach, \& Zilber, 1998). Moreover, teachers' stories about their students may not be neat or proceed chronologically; rather, stories have layers, they go back and forth in time, possibly including several plotlines and turns (Lieblich et al., 1998; Plunkett, 2001; Polkinghorne, 1995).

In this paper, we explore the six teachers' experiences on their diverse relationships with the named students. Our research questions are:

1.How do the teachers narrate their relationships with their students?

2.How do the teachers narrate other relationships regarding the students?

3. How do the teachers narrate change in their relationships with their students?

In the preliminary analysis, after having read each teacher's answers to both questionnaire questions, we decided to analyse them as one story per teacher. This was justified by the way in which the teachers wrote their answers: as a single account in which the two answers formed a continuum. Moreover, we selected the stories of the six teachers (Table 1) who described the most challenging situations for more detailed analysis. Four of the teachers were female and two male, and they were between 24 to 38 years old. Two of the teachers worked in junior high school with grades 7-9 (aged 13 to15 years) and four in primary school with grades $1-4$ (aged 7 to 10). All the students were boys.

\section{TABLE 1}

Description of the participants 


\begin{tabular}{lll}
\hline Alias & Student in grade & Age \\
\hline Eva & 1 & 26 \\
Camilla & 7 or 9 & 25 \\
Mats & 4 & 38 \\
Rita & 4 & 25 \\
Sara & 3 & 24 \\
Tomas & 8 & 26 \\
\hline
\end{tabular}

\subsection{Analysis of the stories}

In the detailed analysis of the narratives (Clandinin \& Connelly, 2000; Polkinghorne, 1995; Riessmann, 2008), we focused on different characteristics in the teacher-student relationship. We first analysed the six stories separately to map the diversity of each teacher's experiences. Regarding content, we analysed the topics in the stories, the temporal dimensions of the story (the past, the present, possible future prospects) and the social dimension (the people in each story and their role in it). In particular, we applied positioning analysis (van Langenhove \& Harré, 1999) to see how the teachers positioned themselves and others in the stories. We also paid attention to the teachers' emotions, explicit or implicit, in the stories. Regarding structural elements, we looked for turns in the stories and their location, and for any explicit signs of contradictions (e.g. "but"). In practice, the content and structural analytical elements were intertwined. For example, temporality was analysed on the basis of the words ("earlier") and tenses used; likewise, shades of meaning are embedded in the particular word choices in one's narrative.

In the second phase (Table 2), we compared the six stories. This revealed commonalities and differences between the stories and also omitted some parts of them. Four storylines on the teacher-student relationship were identified: these were labelled problems in the relationship, sincerity and fondness, support from other adults, and shifts in the relationships. By storyline, we refer to the narrative frame(s) within which any particular episode is narrated (Harré \& Moghaddam, 2014). Another option would have been to present 
each teacher's story in full; however, the storylines are simply a means to highlight the main dimensions of the teacher-student relationships found across the stories; not all the storylines appear in each of the six stories.

\section{TABLE 2}

Comparison of the stories and identification of the storylines across the stories

\begin{tabular}{lcccc}
\hline \multirow{2}{*}{ Alias } & \multicolumn{3}{c}{ Four storylines on teacher-student relationships } \\
\cline { 2 - 5 } & Problems & $\begin{array}{c}\text { Sincerity and } \\
\text { fondness }\end{array}$ & Support & Shifts \\
\hline Eva & $\mathrm{x}$ & $\mathrm{x}$ & $\mathrm{x}$ & $\mathrm{X}$ \\
Camilla & $\mathrm{x}$ & & $\mathrm{x}$ & $\mathrm{x}$ \\
Mats & $\mathrm{x}$ & & $\mathrm{x}$ & $\mathrm{x}$ \\
Rita & $\mathrm{x}$ & $\mathrm{x}$ & $\mathrm{x}$ & \\
Sara & $\mathrm{x}$ & $\mathrm{x}$ & $\mathrm{x}$ \\
Tomas & $\mathrm{x}$ & & & \\
\hline
\end{tabular}

To verify the findings, we discussed our views and interpretations after having read the data individually, and subsequently throughout the analytical process. It also became clear that even though the data had been collected early in the study, the teachers' stories appeared to contain rather timeless themes. After the analysis, the original data extracts were translated from Swedish into English with the aim of evoking the same shades of meaning despite the differences in grammatical rules and idioms between the two languages.

In the findings section, all quotes from the teachers' narratives are original and accurate. Omits within a quote are marked with three spaced ellipsis points (. . .) and any additional clarifications with square brackets [ ].

\section{Four storylines about teacher-student relationships}

The findings are presented according to the four storylines. The first storyline, problems, is divided into two contexts: problems in the classroom and problems at home. The second storyline is about sincerity and fondness in the teacher-student relationship, and the third is about the support the teachers sought for the students from other adults. The fourth 
storyline, the shifts the teachers experienced in their relationships with the student, is illustrated through three examples. The quotes are marked with the teacher's alias, which makes it possible to combine the individual stories and follow each teacher in their unique professional and practical landscapes.

\subsection{Problems narrated in the relationships}

The first storyline is about the problems the teachers experienced with the student. The problems had two main settings: classroom and home. All the teachers narrated problems regarding the student, but the nature, seriousness and setting of the problem varied.

\subsubsection{Problems in the classroom}

In every teacher's story, the classroom was a site where the students had problems with their peers and with the teacher. A common problem in the classroom was the student's inappropriate and aggressive behaviour: "kicking and hitting, tearing up books, throwing things" (Sara). The problems the teacher had with the student were often narrated as something the student did on purpose as a show of resistance to the official norms of the school, such as when "[he] disobeyed instructions" (Camilla) or as something occurring unintentionally, such as "[he] can sometimes have outbursts" (Sara). Furthermore, whether intentional or not, such "outbursts" were narrated by the teachers as directed towards themselves, although they also brought the student into the argument by explaining how the student "ruined things for me [the teacher] as well as the rest of the class" (Camilla). In general, the teacher and the class were perceived as victims of the student in question whose behaviour and actions occurred "at the expense of his classmates and me" (Rita). Personal characteristics of the student making good relationships hard to build/ maintain were also mentioned: "a very insecure, obstinate and aggressive boy" (Mats). 
The student was occasionally narrated as not being mean on purpose. For example, Eva wrote that she had a student "that one can consider as 'causing trouble', sometimes through his way of acting up"; Camilla, like Eva, described how the (same) student "is feeling a lot better now", indicating that the bad behaviour alluded to was due to the student feeling bad. Moreover, Rita used very vague expressions in introducing the background to the student's "outbursts":
A very intense boy who is always there [when] things happen.
He has a hot temperament and on some occasions it has erupted over his classmates and me.

Rita begins her story with a rather neutral expression, "intense" (line 1), and adds a general notion about how the boy is always present when things happen (lines 2-3); another interpretation might be that things always happen when he is around. Even after clearly describing him as having "a hot temperament" (line 4) the teacher narrates how his temperament, not the boy personally, "has erupted over his classmates and me" (lines 6-7). Tomas, in his response to the question of a student who has caused trouble, begins his story by describing the student with simple facts: "Boy. Age 15 years, grade 8 . Smart but totally unmotivated". The problem in Tomas' story lies in the contradiction between what the teacher thinks the student could do as a "smart" student and the student's attitude towards studying, his being "unmotivated". Thus, Tomas is combining a permanent characteristic ("smart") with an intentional way of being ("unmotivated") and making the contradiction explicit with the conjunction "but".

\subsubsection{Problems at home}

The problems that the students faced in their family relations was often narrated as the origin of their problems in the classroom. The teachers narrated the problems in their 
relationships with the student as related to the student and yet also as something the student had no control over; in particular, students were often narrated as the victim of their home situation. For example, for Mats the student had "a very messy domestic situation" which made the student "insecure"; for Sara, the student "can sometimes have tantrums . . . in adverse situations" because at home, he "gets his own way a lot". It is noteworthy how the descriptions of the student's domestic problems varied from the very general "problems at home" (Tomas) to the more detailed [he] "gets his way a lot [at home]" (Sara), or even as naming a family member as behind the student's behaviour: "I believe that mum is the culprit." (Tomas). In sum, the teachers tended to locate the students' problems in their relationships at home.

\subsection{Sincerity and fondness}

The teachers reported frequently receiving spontaneous expressions of fondness from their young students in the classroom, which caused the relationship to take on some of the features of a parent-child relationship. The second storyline is about these sincere expressions of fondness that were rather commonly storied as an integral part of the teachers' relationships with their 7 - to 10 -year-old students.

The teachers narrated the student's physical expressions of affection in a tone of acceptance, as positive features of the relationship. One teacher, after describing how the firstgrader had problems of concentration in the classroom, then described, with "BUT" in capital letters, how the student "also hugs and kisses me occasionally..." (Eva). Another student who is "very affectionate" and "a smart boy who likes to tell [the teacher] his ideas" wants to "sit in the [teacher's] lap, hold hands" (Sara). In these stories, the student is not considered a mere learner but is positioned as a little child with age-appropriate behaviour. Moreover, in the first excerpt, the "hugs and kisses" appear to compensate for the academic problems the student is facing, whilst in the second story the teacher narrates the boy, when he displays affectionate 
behaviour, as "a smart boy". A possible interpretation is that the teachers experience their students' age-appropriate behaviour as nothing more or nothing less than that. This might be the reason for the lack of explicit notions about the student's age in these stories.

\subsection{Narrated support from other adults}

The teachers were in active collaboration with parents and other professionals on their problems with their student. The third storyline is about the teachers' experiences of support regarding the student.

At their briefest, the teachers' narratives on support were in the form of notes about others' contribution to the situation, e.g., "Police + social [work/ers] involved." (Tomas). With no references to anything personal, the teacher merely states a fact. Nevertheless, the situation can be considered rather serious as the stakeholders involved include police and social services, both of which are not to be bothered over trifling matters, which renders the teacher's neutral tone noteworthy. The statement gives little scope for interpretation of how the teacher actually experienced such outsider involvement, or whether the teacher has been in contact with the police and/or social services, or whether they have been involved with the student outside school. Since the fact is the concluding statement of Tomas' narrative about the student, it would appear that the story continues, that the situation remains to be resolved, while at the same time, it sounds as if the teacher is saying that the even if the situation is not under control, at least something is being done to help the student.

In most narratives, the teachers worked together with other adults, as "we", indicating collective support on the question of the problem student, with the teachers positioning themselves as a part of that support network. This collective "we" mainly used "conferences" as a means to support the student: "At a parent-teacher conference we agreed on a common 'plan' together with him" (Eva). The composition of these "conferences" comprised, at their 
smallest, the teacher and the boy's parents, and were expanded when necessary. For example, Mats draws a picture where the student, Daniel, is provided with a long list of supporters.

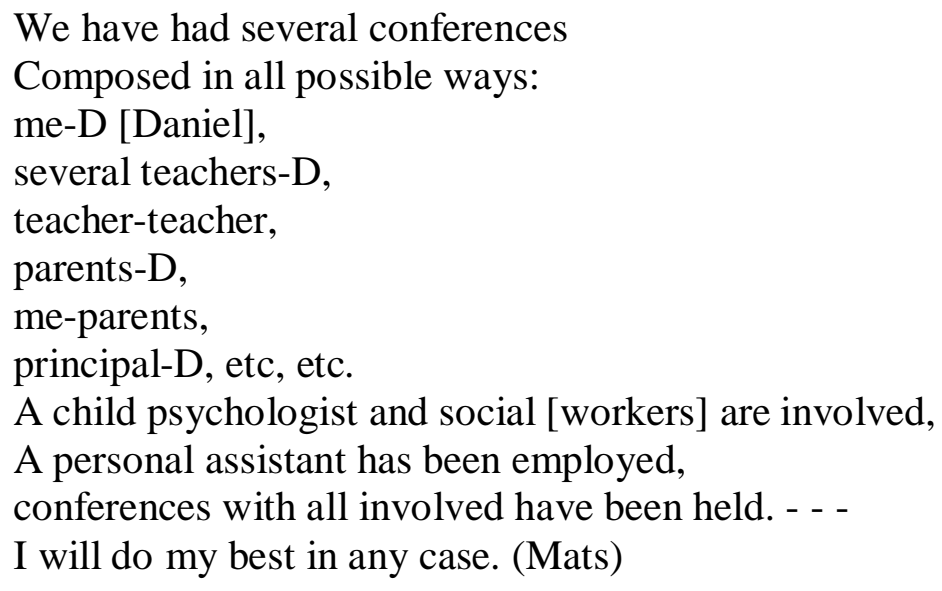

In addition to describing a seemingly complete list of people and actions to support the student in the first excerpt, Mats highlights the issue by being very explicit: "all possible" (line 2) people "are involved" (line 9) and "all involved" (line 11) collaborate with each other. After this detailed description of the collective network, the teacher, in the end of a rather long story, re-positions himself as an individual "I" (line 12) and no longer as part of the collective "we" (line 1) or "all" (line 11). By so doing, he separates himself from the others, as he cannot be sure of their engagement in the student's well-being in a situation where he is determined to help the student: "I will do my best in any case" (line 12).

The second example is drawn from the story by Sara, and focusses on the very beginning of a formal support process.

1 A psychologist is on the case -

2 he [the student] confides [to the psychologist],

3 is able to convey his thoughts.

4 We are thinking about

5 contacting a child psychologist. (Sara)

In this early phase of supporting the student, only "a psychologist is on the case" (line 1). Positive things follow as the student "confides" (line 2); yet it is not enough that the student "is able to convey his thoughts" (line 3). Therefore, the teacher, together with 
anonymous others, again the collective "we" (line 4), will proceed to the next step of “contacting a child psychologist" (line 5). Time seems to move slowly here. "We are thinking about" (line 4) is indecisive, the decision has not yet been made but "we" are considering the next step. Nevertheless, in this small story the process evolves step by step as additional people are introduced one after another. The teacher remains in the background, not really visible in the process, in comparison to the first example by Mats where everything has been done and the teacher promises to be there for the student even if everybody else fails.

In both examples support is narrated as a process amidst which the teachers work. Likewise, the stories seem to indicate that the more people, the more support - that collaboration and support go hand in hand in the teacher-student relationship.

\subsection{Narrated shifts in the relationships}

The storyline below is illustrated through three examples about shifts in teacher-student relationship, that is, how from the teachers' perspective the relationship changes when the student's behaviour changes. In some examples the reasons for the change are more obvious than in others. Very different types of changes occur on the emotional level: Mats becomes closer to the student while Camilla's main emotion is relief. Moreover, Mats focuses on the teacher-student relationship, and Camilla on her personal sense of relief and the relationship between the student and his classmates. Tomas and Mats, in turn, concentrate on building trust with the student. Although the two students concerned are of different ages, a fourthgrader "little boy" (Mats) and an eight-grader "big boy" (Tomas), both teachers narrate trust as developing over time and being closely related to the teacher's emotions.

\subsubsection{Living in the moment}

Tomas described his relationship with the student in the eighth grade on a very general level. Unlike the other teachers' stories, Tomas' story had no past or future as if the 
relationship was unfolding from moment to moment. Change was a permanent characteristic of the relationship.

I have a good relationship with him, but he often lets both himself and me down. /. . . I His offering me a treat could be a way of saying 'thanks', 'I'm sorry' or 'I like you'. All ways of expressing oneself are allowed.

Within the description on the general level, the complexity of the relationship is apparent. Tomas describes his relationship with the student as "a good relationship" (line 1) and continues in the same sentence to describe how the student frequently fails his own and the teacher's expectations and "lets [them] both ... down" (line 2). Another tension occurs between the student's behaviour which "lets [them] both . . . down" (line 2) and the student's attempts to retain contact the teacher by "offering [the teacher] a treat" (line 3). The teacher narrates himself as very sensitive in relation to the student's rather discrete communication, and leaves plenty of room for interpretation of the student's thoughts and emotions. The teacher mentions in particular a few possible interpretations for what the student, "offering [him] a treat could be ... saying" (line 3). The three alternative explanations of the student's behaviour, "'thanks', 'I'm sorry', or 'I like you"” (line 4) are very different, but together with the act of "offering [the teacher] a treat" (line 3) it seems as if the student is trying to tell the teacher that he is an important person to him. Tomas concludes his story with a very openended statement: "All ways of expressing oneself are allowed" (line 5). In this context, the phrase could be interpreted to mean that the teacher is allowing the student to express himself in a variety of ways, but it can equally indicate that all means of expressing oneself are allowed for both the student and the teacher because they have a "good relationship" (line 1). In sum, the teacher experiences "a good relationship" (line 1) as a mutual bond between him and the student, yet the key to this relationship lies in the teacher's interpretation of the student's behaviour. 


\subsubsection{The early signs of trust}

The story told by Mats about his fourth grade (10-year-old) student illustrates how trust builds over time in the teacher-student relationship, and how this in turn results in enhanced emotions. The teacher's confession-like warmth is narrated as a response to the apparent vulnerability of the student. The excerpt is located after the teacher has described a long list of collaborators involved in the student's situation.

[The fourth-grader] has started to show emotions of sadness and disappointment in himself when he's done something wrong. [. . .]

He says that he cares about me and that he wants me to care about him. For him to say something like that is something totally new. My heart goes out for this little guy.

The fourth-grader, or "little guy", as Mats calls him, expresses himself openly and explicitly, by showing his emotions (lines 1-3), saying he likes the teacher (line 5) and hopes the teacher returns these feelings (line 6). For the teacher, the student's "sadness and disappointment in himself when he's done something wrong" (lines 3-4), in particular, seem to indicate that the student trusts the teacher. The teacher closes his story by directly expressing the emotions he feels towards the student, stating how his "heart goes out for this little guy" (line 9), as if he truly feels for the student. Although the teacher narrates mutual affection in the relationship, the story lacks clues on the temporal dimension of its development from the teacher's side. Nevertheless, in acknowledging the trust the student "has started" (line 1) to show towards the teacher, the teacher is clearly distinguishing between the present and a time when the student did not "show emotions of sadness" (lines 12). Similarly, the freshness of the situation is explicit in the teacher's comment on the situation as "something totally new" (line 8). In sum, Mats' story is about a development process that has not yet come to an end. 


\subsubsection{From one extreme to another}

Camilla's story is an example of how a student's behaviour can change very quickly, leading to a change in the whole classroom from one extreme to another. The change happened after a network of adult relationships had been built around the student, whose biggest mistake seemed to be disobeying the teacher's orders. In the following excerpt, the teacher writes about a difficult situation with a new student during the first weeks, describing the gravity of her position as "the most difficult [situation] I have ever been in". The teacher was so stressed by it that she was "close to resigning."
After a long discussion with him one afternoon together with support measures (including a school welfare officer/psychologist) he has completely changed and is now one of the better students in the class. The devastating effect that he had on the class in the beginning, is equalled only by the positive influence he has now.

The improvement is narrated very dramatically in terms of the student having "completely changed" (line 5), as if nothing is left of the student who caused trouble when he first arrived in the classroom. Moreover, the teacher can identify the precise moment, "one afternoon" (line 2) that seemed to cause the dramatic change. It is noteworthy how the followon expression "better students in the class" (line 6) seems to indicate that the student was originally considered to belong to a group of students other than the "better students" and thus alludes to the students in the class as a hierarchy. Moreover, regardless of whether the dramatic change is seen as an internal event or as something strictly between the student and the teacher, it is clear that the student's original behaviour had an "effect" (line 7) on the whole class. Between the lines, Camilla appears to be telling a story about her relief and surprise at the turnaround in the situation. Another level of the story, besides that of the teacher and the student, concerns the student in relation to his classmates. In sum, the story draws a picture of the classroom as a network of relationships that affect each other. 


\section{Discussion: keys to success when facing a difficult relationship with a student}

The purpose of this paper was to explore, through six teachers' personal stories, teacherstudent relationships as an integral part of a teacher's professional knowledge landscape. In the following sections, we will discuss how the presented four storylines with their unique details on the teacher-student relationships can contribute on the literature on teachers' knowledge landscapes. In addition, the Nordic context where the original research project was located will be discussed from and international perspective.

Teacher burnout, job satisfaction and intent-to-leave are complex and related entities where emotions and emotional exhaustion play a crucial role (Chang, 2009; Martin et al., 2012). Teachers' practical knowledge is always context-dependent (Clandinin \& Connelly, 1996), and hence the four storylines illustrated how emotions and relational considerations are integral to the professional judgments that teachers make (cf. Frelin, 2014). Because relationships with students are an important source of sustained teacher commitment (Fransson \& Frelin, 2016), their quality is an important key to decreasing teacher attrition. Teacher-student relationships are not role relationships alone, but are formed by two persons with full lives. However, in these stories, the life spheres present were mostly those of the student - the teachers did not reveal much about their own life situations and how these might have affected their relationships with the student. Nevertheless, the teachers' stories provide glimpses into their personal and professional landscapes. In particular, the stories emphasised an important component of teacher knowledge, i.e., teachers' knowledge of learners and their characteristics (Shulman, 1987). On the one hand, the stories brought out the importance of knowledge not only of the personal characteristics of the student in question but also of his or her domestic (family) situation and other relations outside school. On the other hand, the teachers positioned themselves as very understanding and considerate with respect to the student's problems, rather than simply labelling the student as bad. This may constitute an 
argument for teachers building close and personal relationships with their students when faced with difficult relationships (see also, e.g., Cornelius-White, 2007; Johnson, 2008).

One contribution of the study lies in the details the stories provide on the ecological nature of the teacher-student relationship, embedded as it is in a network of other relationships reaching far beyond the individual classroom and learning situation. For example, collaboration with parents can be a significant source of support in a challenging situation, but if collaboration fails, the teacher may, like those in this study, take on the responsibility to organise other sources of support for the student. In such cases, the teacher's role in a student's life can become highly significant. In essence the teachers were saying that if a student is not feeling well, matters other than those related to studying and learning need to be taken care of first and they include themselves as responsible for doing so.

The stories indicated that the fact that the teachers considered their students holistically, as complex and unique individuals, facilitated finding means to navigate the challenging relationship in a way that was positive for the student's learning. In line with other research on the relation between student well-being and learning (see e.g. Noble et al., 2008), the teachers emphasised the importance of student well-being in their stories as the problems at issue were not confined solely to within the student as an individual but were reflected in the dynamics of the classroom, involving both the teacher and the student's classmates, which argues for a relational framing of the problem.

The Nordic perspective adopted in this paper might be considered a limitation on the transferability of the findings. However, we would rather see the present teacher narratives as offering a fruitful starting-point for cross-cultural learning through reflection: different perspectives often provoke ideas and suggestions of relevance to one's own professional and practical landscapes. Of course, teachers' work is always constructed on several micro and macro levels, such as the level of autonomy they have in and out of the classroom, the 
relationship between home and school, and the level of the test-orientation of the school and society.

One conclusion from this study is that relationships matter in additional ways than we normally consider in education. They can make a difference. In difficult situations, one trustworthy adult who puts effort into building trust and a supportive network and coordinates the network to support a student can make a significant difference in that student's life. Difficult relationships can also be rewarding relationships, if the teacher has the appropriate capacity in the right conditions (personally, professionally, and especially with respect to autonomy) to put effort into a student. This is important not only for the well-being and learning of students but it is also an issue of equality. The Nordic school system studied here supports continuing relationships by keeping a teacher with the same class of students for several years. The present results included one example in which the teacher reported being about to give up on a new student, before they had got to know each other. Teachers are not teaching machines whose only task is to deliver content, but they are professional human beings with feelings and personalities who also care about their students (cf. Frelin, 2013). As a result, several small stories were about improvement in the teacher-student relationship over time, either due to increased closeness, which awoke a teacher's emotions, or improvements in student behaviour or academic performance. Such rewards are considered to be conducive to sustained commitment to the teaching profession (Fransson \& Frelin, 2016; Gu, 2014; Gu \& Day, 2013; O'Connor, 2008). These messages probably find common ground with teachers around the world.

This study has implications for state- and school-level administration as well as for teacher education. Teacher-student relationships require more attention throughout the education system, starting from initial teacher education, where student teachers need to be trained in the skills needed to build and maintain good and supportive relationships with their 
students. In schools, support should be available and easy to access when necessary, and teachers encouraged to ask for support in time, both for themselves and for their students. Moreover, teachers need time and opportunities to learn to know their students, a demanding task in a global and local environment that strongly emphasises academic learning and test results.

\subsection{Limitations of the study and further research}

This study considered teachers' perspectives only; however, every relationship has two parties. Thus, more research is needed to explore students' stories about their relationships with teachers, as teachers' perceptions of good relationships with students do not always match those of students (Veldman et al., 2013). In particular, in situations where the teacher identifies problems in the relationship, more attention should be paid to the student's experiences of the teacher's actions and intentions, as the experiences may be rather unexpected and even unpleasant (Honkasilta et al., 2016). Moreover, the data was collected two decades ago; yet the essence of teacher-student relationships can be assumed to have remained the same. The stories could have been from very recent data.

Although the dataset used in this paper was small, the detailed narrative analysis with an emphasis on the relationality and multiplicity of teachers' experiences, including contradictory ones contributes to the literature on teacher commitment by adding knowledge about teachers' ways of handling challenging relationships and even how rewarding this can be. Many countries suffer from a shortage of teachers, and schools known for challenges in teacher-student relationships tend to have the hardest time finding experienced teachers. Increasing knowledge on the rewards that such relationships can bring, and ways of building and sustaining them, would seem to be worthwhile for teachers and may be life-changing for their students. 


\section{References}

Aultman, L. P., Williams-Johnson, M. R. \& Schutz, P. A. (2009). Boundary dilemmas in teacher-student relationships: Struggling with "the line". Teaching and Teacher Education, 25(5), 636-646. doi:10.1016/j.tate.2008.10.002

Ball, D. L. \& Wilson, S. M. (1996). Integrity in teaching: Recognizing the fusion of the moral and intellectual. American Educational Research Journal, 33(1), 155-192.

Ben-Peretz, M. (2011). Teacher knowledge: What is it? How do we uncover it? What are its implications for schooling? Teaching and Teacher Education, 27, 3-9. doi:10.1016/j.tate.2010.07.015

Brackett, M. A, Reyes, M. R., Rivers, S. E, Elbertson, N. A. \& Salovey, P. (2011). Classroom emotional climate, teacher affiliation, and student conduct. Journal of Classroom Interaction, 46(1), 27-36.

Chang, M.-L. (2009). An appraisal perspective of teacher burnout: Examining the emotional work of teachers. Educational Psychology Review, 21, 193-218. doi: 10.1007/s10648009-9106-y

Claessens, L., van Tartwijk, J., Pennings, H., van der Want, A., Verloop, N., den Brok, P. \& Wubbels, T. (2016). Beginning and experienced secondary school teachers' self- and student schema in positive and problematic teacher-student relationships. Teaching and Teacher Education, 55, 88-99. doi:10.1016/j.tate.2015.12.006

Clandinin, D. J. \& Connelly, F. M. (1995). Teachers' professional knowledge landscapes. New York: Teachers' College.

Clandinin, D. J. \& Connelly, F. M. (1996). Teachers' professional knowledge landscapes: Teacher stories. Stories of Teachers. School stories. Stories of schools. Educational Researcher, 25(3), 24-30.

Clandinin, D. J., Downey, C. A. \& Huber, J. (2009). Attending to changing landscapes. Shaping the interwoven identities of teachers and teacher educators. Asia-Pacific Journal of Teacher Education, 37(2), 141 - 154.

Clandinin, D. J. \& Rosiek, J. (2007). Mapping landscape of narrative inquiry: borderland spaces and tensions. In D. J. Clandinin (Ed.) Handbook of narrative inquiry. Mapping a methodology (pp.35-75). Thousand Oaks, CA: SAGE.

Colleague et al. (2014). [details removed for peer review]

Colleague et al. (2016). [details removed for peer review]

Collie, R. J., Shapka, J. D. \& Perry, N. E. (2011). Predicting teacher commitment: The impact of school climate and social-emotional learning. Psychology in the Schools, 48(10), 1034-1048.

Connelly, F. M., Clandinin, D. J. \& Ming Fang, H. (1997). Teachers' personal practical knowledge on the professional knowledge landscape. Teaching and Teacher Education, 13(7), 665.

Cornelius-White, J. (2007). Learner-centered teacher-student relationships are effective: A meta-analysis. Review of Educational Research, 77(1), 113-143. doi: $10.3102 / 003465430298563$

Cortazzi, M. \& Lin, L. (2006). Asking questions, sharing stories and identity construction: sociocultural issues in narrative research. In S. Trahar (Ed.) Narrative research on learning: Comparative and international perspectives (pp. 27-46). Oxford, UK: Symposium Books.

Craig, C. J. (2013). From stories of staying to stories of leaving: A US beginning teacher's experience. Journal of Curriculum Studies, 46(1), 81-115. doi: $10.1080 / 00220272.2013 .797504$ 
Davidson, A. L. (1999). Negotiating social differences: Youths' assessments of educators' strategies. Urban Education, 34(3), 338-369. doi:10.1177/0042085999343004

Davis, H. A. (2003). Conceptualizing the role and influence of student-teacher relationships on children's social and cognitive development. Educational Psychologist, 38(4), 207 234.

Day, C. \& Gu, Q. (2010). The new lives of teachers (1st ed.). London, New York: Routledge.

Day, C. \& Gu, Q. (2014). Resilient teachers, resilient schools: Building and sustaining quality in testing times. New York: Routledge.

Day, C., Sammons, P., Stobart, G., Kingston, A. \& Gu, Q. (2007). Teachers matter. Connecting work, lives and effectiveness. Maidenhead: Open University Press.

den Brok, P., Levy, J., Brekelmans, M. \& Wubbels, T. (2005). The effect of teacher interpersonal behaviour on students' subject-specific motivation. Journal of Classroom Interaction, 40(2), 20-33.

Doyle, W. (2006). Ecological approaches to Classroom Management. In C. M. Evertson \& C. S. Weinstein (Eds.), Handbook of classroom management: Research, practice, and contemporary issues (pp. 97-126). Mahwah, N.J.: Lawrence Erlbaum Associates.

Elbaz, F. (1983). Teacher thinking: A study of practical knowledge. London, New York: Croom Helm; Nichols.

Eldor, L. \& Shoshani, A. (2016). Caring relationships in school staff: Exploring the link between compassion and teacher work engagement. Teaching and Teacher Education, 59, 126-136. doi: 10.1016/j.tate.2016.06.001

Entwistle, N., Skinner, D., Entwistle, D. \& Orr, S. (2000). Conceptions and beliefs about "Good teaching": An integration of contrasting research areas. Higher Education Research \& Development, 19(1), 5-26.

Evertson, C. M. \& Weinstein, C. S. (2006). Classroom Management as a field of inquiry. In C. M. Evertson \& C. S. Weinstein (Eds.), Handbook of classroom management: Research, practice, and contemporary issues (pp. 3-15). Mahwah, N.J.: Lawrence Erlbaum Associates.

Fransson, G. \& Frelin, A. (2016). Highly committed teachers: What makes them tick? A study of sustained commitment. . Teachers and teaching: Theory and practice, 22(8). doi:10.1080/13540602.2016.1201469

Frelin, A. (2013). Exploring Teachers' Relational Professionalism in Schools. Rotterdam: Sense Publishers.

Frelin, A. (2014). Professionally present - highlighting the temporal aspect of teachers' judgment. Teacher Development, 18(2), 264-273.

Grossman, P.L. (1995). Teachers' knowledge. In L. W. Anderson (Ed.), International encyclopedia of teaching and teacher education (pp. 20-24). Oxford: Pergamon.

$\mathrm{Gu}, \mathrm{Q}$. (2014). The role of relational resilience in teachers' career-long commitment and

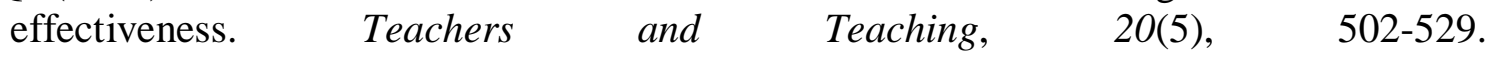
doi:10.1080/13540602.2014.937961

Gu, Q. \& Day, C. (2013). Challenges to teacher resilience: Conditions count. British Educational Research Journal, 39(1), 22-44. doi:10.1080/01411926.2011.623152

Hamre, B. K., \& Pianta, R. C. (2001). Early teacher-child relationships and the trajectory of children's school outcomes through eighth grade. Child Development, 72(2), 625-638. doi:10.1111/1467-8624.00301

Hargreaves, A. (1998). The emotional practice of teaching. Teaching and Teacher Education, 14(8), 835.

Hargreaves, A. (2000). Mixed emotions: Teachers' perceptions of their interactions with students. Teaching and Teacher Education, 16(8), 811. 
Hattie, J. (2009). Visible learning: a synthesis of over 800 meta-analyses relating to achievement. London; New York: Routledge.

Honkasilta, J., Vehkakoski, T. \& Vehmas, S. (2016). 'The teacher almost made me cry' Narrative analysis of teachers' reactive classroom management strategies as reported by students diagnosed with ADHD. Teaching and Teacher Education, 55, 100-109. doi: 10.1016/j.tate.2015.12.009

Johnson, B. (2008). Teacher-student relationships which promote resilience at school: A micro-level analysis of students' views. British Journal of Guidance \& Counselling, 36(4), 385-398. doi:10.1080/03069880802364528

Kelchtermans, G. (2009). Who I am in how I teach is the message: Self-understanding, vulnerability and reflection. Teachers and teaching: Theory and practice, 15(2), 257 272.

Lee, S.-J. (2007). The relations between the student-teacher trust relationship and school success in the case of Korean middle schools, Educational Studies,33(2), 209-216. DOI: $10.1080 / 03055690601068477$

Lieblich, A., Tuval-Mashiach, R. \& Zilber, T. (1998). Narrative research: Reading, analysis and interpretation. Thousand Oaks (Calif.): Sage.

Lingard, B., Hayes, D. \& Mills, M. (2003). Teachers and productive pedagogies: Contextualising, conceptualising, utilising. Pedagogy, Culture \& Society, 11(3), 399424. Retrieved from http://www.informaworld.com/10.1080/14681360300200181

Margonis, F. (2004). From student resistance to educative engagement: A case study in building powerful student-teacher relationships. In C. W. Bingham \& A. M. Sidorkin (Eds.), No education without relation (pp. 39-53). New York: Peter Lang.

Mackenzie, S. (2013). Achievers, confidence-builders, advocates, relationship-developers and system-changers: What 'making a difference' means to those who work with children with special educational needs - a typology of rewards. Teachers and Teaching, 19(4), 433-448. doi:10.1080/13540602.2013.770227

Martin, N. K., Sass, D. A. \& Schmitt, T. A. (2012). Teacher efficacy in student engagement, instructional management, student stressors, and burnout: A theoretical model using inclass variables to predict teachers' intent-to-leave. Teaching and Teacher Education, 28, 546-559. doi:10.1016/j.tate.2011.12.003

Morgan, M., Ludlow, L., Kitching, K., O'Leary, M. \& Clarke, A. (2010). What makes teachers tick? Sustaining events in new teachers' lives. British Educational Research Journal, 36(2), 191-208. doi: 10.1080/01411920902780972

Nias, J. (1996). Thinking about feeling: the emotions in teaching. Cambridge Journal of Education, 26(3), 293 - 306.

Noble, T., Wyatt, T., McGrath, H., Roffey, S., \& Rowling, L. (2008). Scoping Study into Approaches to Student Wellbeing: Final Report. Brisbane: Australian Catholic University and Erebus International. Retrieved from https://docs.education.gov.au/documents/scoping-study-approaches-student-wellbeingfinal-report

Nussbaum, M. C. (1997). Emotioner som värdeomdömen. In U. M. Holm, E. Mark \& A. Persson (Eds.), Tanke, känsla, identitet (pp. 197-234). Göteborg: Anamma.

O'Connor, K. E. (2008). "You choose to care": Teachers, emotions and professional identity. $\begin{array}{llll}\text { Teaching } \text { and Teacher } & \text { 117-126. }\end{array}$ doi:http://dx.doi.org/10.1016/j.tate.2006.11.008

OECD. (2011). Building a high-quality teaching profession: Lessons from around the world. Paris: Organisation for Economic Co-operation and Development.

Pennings, H. J. M., van Tartwijk, J., Wubbels, T., Claessens, L. C. A., van der Want, A. C. \& Brekelmans, M. (2014). Real-time teacher-student interactions: A dynamic systems 
approach. Teaching and Teacher Education, 37, 183-193. doi:http://dx.doi.org/10.1016/j.tate.2013.07.016

Pianta, R. C. (2006). Classroom management and relationships between children and teachers: Implications for research and practice. In C. M. Evertson \& C. S. Weinstein (Eds.), Handbook of classroom management: Research, practice, and contemporary issues (pp. 685-710). Mahwah, N.J.: Lawrence Erlbaum Associates.

Plunkett, M. (2001). Serendipity and agency in narratives of transition: Young adult women and their careers. In D. P. McAdams, R. Josselson, \& A. Lieblich (Eds.), Turns in the road: Narrative studies of lives in transition (pp. 151-176). Washington (DC): American Psychological Association.

Polkinghorne, D. E. (1995). Narrative configuration in qualitative analysis. In J. A. Hatch, \& R. Wisniewski (Eds.), Life history and narrative (pp. 5-23). London: Falmer Press.

Rodgers, Carol R., \& Raider-Roth, Miriam B. (2006). Presence in teaching. Teachers and Teaching, 12(3), 265-287.

Roorda, D. L., Koomen, H. M. Y., Spilt, J. L. \& Oort, F. J. (2011). The influence of affective teacher-student relationships on students' school engagement and achievement: A meta-analytic approach. Review of Educational Research, 81(4), 493-529. doi:10.3102/0034654311421793

Sammons, P., Day, C., Kington, A., Gu, Q., Stobart, G., \& Smees, R. (2007). Exploring variations in teachers' work, lives and their effects on pupils: key findings and implications from a longitudinal mixed-method study. British Educational Research Journal, 33(5), 681 - 701.

Shulman, L. S. (1987). Knowledge and Teaching: Foundations of the new reform. Harvard Educational Review, 57(1), 1-22.

Shulman, L. S. (2004). The wisdom of practice: Essays on teaching, learning, and learning to teach. San Francisco: Jossey-Bass.

Skaalvik, E. M. \& Skaalvik, S. (2011). Teacher job satisfaction and motivation to leave the teaching profession: Relations with school context, feeling of belonging, and emotional exhaustion. Teaching and Teacher Education, 27, 1029-1038. doi:10.1016/j.tate.2011.04.001

Sprott, J. B. (2004). The development of early delinquency: Can classroom and school climates make a difference? Canadian Journal of Criminology \& Criminal Justice, 46, 553-572.

Uitto, M., Jokikokko, K. \& Estola, E. (2015). Virtual special issue on teachers and emotions in Teaching and Teacher Education (TATE) in 1985-2014. Teaching and Teacher Education, 50, 124-135. doi:10.1016/j.tate.2015.05.008

Veldman, I., van Tartwijk, J., Brekelmans, M. \& Wubbels, T. (2013). Job satisfaction and teacher-student relationships across the teaching career: Four case studies. Teaching and Teacher Education, 32, 55-65. doi:10.1016/j.tate.2013.01.005

Wentzel, K. R., Battle, A., Russell, S. L. \& Looney, L. B. (2010). Social supports from teachers and peers as predictors of academic and social motivation. Contemporary Educational Psychology, 35(3), 193-202. doi:10.1016/j.cedpsych.2010.03.002

Wideen, M., Mayer-Smith, J. \& Moon, B. (1998). A critical analysis of the research on learning to teach: Making the case for an ecological perspective on inquiry. Review of Educational Research, 68(2), 130-178.

Woolfolk Hoy, A. \& Weinstein, C. S. (2006). Student and teacher perspectives on classroom management. In C. M. Evertson \& C. S. Weinstein (Eds.), Handbook of classroom management: Research, practice, and contemporary issues (pp. 181-219). Mahwah, N.J.: Lawrence Erlbaum Associates. 
Wu, J.-Y., Hughes, J. N. \& Kwok, O.-M. (2010). Teacher-student relationship quality type in elementary grades: Effects on trajectories for achievement and engagement. Journal of School Psychology, 48, 357-387. doi:10.1016/j.jsp.2010.06.004

Wubbels, T., Brekelmans, M., den Brok, P. \& van Tartwijk, J. (2006). An interpersonal perspective on classroom management in secondary classrooms in the Netherlands. In C. M. Evertson \& C. S. Weinstein (Eds.), Handbook of classroom management: Research, practice, and contemporary Issues (pp. 1161-1191). Mahwah, N.J.: Lawrence Erlbaum Associates.

Zembylas, M. (2007). The specters of bodies and affects in the classroom: A rhizo-ethological approach. Pedagogy, Culture and Society, 15(1), 19-35. doi: $10.1080 / 14681360601162030$ 